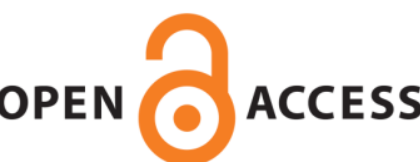

\title{
Perceived manifestations of bullying behaviour in social interactions in school environment
}

Rosinsky, Rastislav ; Čerešníková, Miroslava; Sapouna, Maria; De Amicis, Leyla; Dehue, Francine; Vollink, Trijntje; Willems, Roy; Nikolau, George; Dimakos, Ioannis

Published in:

ICERI2018 Proceedings

DOI:

10.21125/iceri.2018

Published: 01/01/2018

Document Version

Peer reviewed version

Link to publication on the UWS Academic Portal

Citation for published version (APA):

Rosinsky, R., Čerešníková, M., Sapouna, M., De Amicis, L., Dehue, F., Vollink, T., Willems, R., Nikolau, G., \& Dimakos, I. (2018). Perceived manifestations of bullying behaviour in social interactions in school environment. In L. Gómez Chova, A. López Martínez, \& I. Candel Torres (Eds.), ICERI2018 Proceedings: 11th International Conference of Education, Research and Innovation November 12th-14th, 2018 - Seville, Spain (pp. 8779-8785). (ICERI Proceedings). International Academy of Technology, Education and Development. https://doi.org/10.21125/iceri.2018

\section{General rights}

Copyright and moral rights for the publications made accessible in the UWS Academic Portal are retained by the authors and/or other copyright owners and it is a condition of accessing publications that users recognise and abide by the legal requirements associated with these rights. 


\title{
PERCEIVED MANIFESTATIONS OF BULLYING BEHAVIOUR IN SOCIAL INTERACTIONS IN SCHOOL ENVIRONMENT
}

\author{
R. Rosinský1, M. Čerešníková1, M. Sapouna ${ }^{2}$, L. De Amicis ${ }^{2}$, F. Dehue ${ }^{3}$, \\ T. Vollink ${ }^{3}$, R. Willems ${ }^{3}$, G. Nikolau ${ }^{4}$, I. Dimakos ${ }^{4}$ \\ ${ }^{1}$ Constantine the Philosopher University in Nitra (SLOVAKIA) \\ ${ }^{2}$ University of the West of Scotland (UNITED KINGDOM) \\ ${ }^{3}$ Open Universiteit (NETHERLANDS) \\ ${ }^{4}$ University of Patras (GREECE)
}

\begin{abstract}
The paper provides insight into social interactions among primary school pupils in Slovakia focused on manifestations of bullying behaviour. The study was conducted in the sample of 289 pupils with an average age of 10.6 years. Peer interactions are very important for the child's psychosocial development and are of a key importance in the period of adolescence. As many studies from the area of ontogenetic psychology state (for example: Macek, 2013; Santrock, 2013; Di Clemente, 2009), in the period of adolescence individuals start to intensively perceive what their peers think about them and how they perceive them. They need to be a part of peer social groups, have their status in them, and feel they are accepted by others. In this period, there are many changes in the areas of relationships and perceptions of authorities, and adolescents build their own social status in various spheres of life. The developmental role of the period of adolescence is formation of one's identity. The developmental failures can lead to the onset of risk behaviour in adolescents. In the school environment, the frequently identified risk behaviours include bullying (Kolář, 2011; Řičan, Janoušková, 2010; Čerešník, 2016). In the study, we focused on the situations in which pupils feel frightened, insecure, excluded from a group, are physically hurt, or are teased and defamed. We studied the perceptions of such situations by pupils at schools. Furthermore, we focused our attention on the determinants of the onset of bullying behaviour and reactions to such manifestations in the school environment. The findings show that bullying behaviour is most frequently experienced by overweight pupils and pupils who look different. The most frequently identified forms of bullying behaviour include defamation and insulting.
\end{abstract}

Keywords: Bullying, social interaction, overweight pupils.

\section{INTRODUCTION}

The developmental role of the period of school age and adolescence is an ability to integrate into a social group and have a valid status and an adequate social status in it. A basic social group for children is usually the family which mediates the primary influence of culture, teaches them an orientation in the world of symbols, habits, values. For the children's further healthy development, however, it is important to gradually integrate into peer interactions and relationships in a wider social environment. For children, school is a space of institutionalised formal socialisation and also a reference place where children socialise with friends, develop relationships with authorities, learn "how to live" in a concrete society. In the class, in the group of peers, under the teacher's guidance, children acquire and enhance social experience with other people and on its basis then realise their interactions and develop social skills.

In terms of ontogeny, peer interactions become of a key importance in the period of school age ([1], [2]). Children learn to form and maintain peer relationships, friendships stop being made on purpose (you are my friend because you lend me toys), and shared values become important. Furthermore, a vital role is played by social attractiveness and meeting the need to have one's status in the group of peers. Braun, Marková, Nováčková [3] state that during the formation of the school group a loss of class cohesion might occur as a result of the formation of small groups. They are created in accordance with social fondness but also social space in which children live (children from rural areas, children from segregated Roma communities, etc.), family's financial status, family and children's lifestyles, interests, and skills. In some cases, a loss of class cohesion closely relates to exclusion of specific groups and their members from the events in the class and also to direct aggression against them. In the school environment, the frequently identified risk behaviours include bullying ([4], [5], [6]). 
Pupils who are the source of bullying behaviour in the class can often be identified on the basis of aggression, impulsiveness, desire to gain power and influence in the class [7], dominant behaviour [8], and rejection of the school environment [9].

Širǔčková [10] states that motivation, attitudes, self-worth, and self-regulatory mechanisms of personality condition the predisposition to risk behaviour. The extent of motivation to achieve goals and success influences the ways of man's behaviour. With repeated failures, man can choose risk behaviour which can help him achieve the goal or cope with the failure. A regulatory role in risk behaviour is also played by the extent in which man acquires social norms, habits and values. Those who have internalised social norms and feel responsible for the events around them produce risk behaviour less often. On the other hand, people influenced mainly by the norms from outside have tendencies to attribute the consequences of their behaviour to others or a coincidence but not to themselves. They underestimate the consequences of their behaviour and produce risk behaviour more often. In the study, we focused on one of the forms of risk behaviour present in the school class - bullying.

According to Čerešník [6], bullying behaviour belongs to violent and dependency relationships. It is a hostile manifestation in which someone is hurt, humiliated, feels uncomfortable and is not able to defend himself. An intention is to hurt, harm and humiliate. A motive is the use of power and cruelty, overcoming the solitude, killing the boredom, curiosity, jealousy, etc. The victims are helpless and are not able to defend themselves. Dignity is disturbed. The victims are teased and humiliated. That results in self-doubt, a lack of trust, anxiety, depressions, fear of school.

Olweus et al. [7] characterise bullying as recurring aggressive behaviour with an intention to hurt which is accompanied by an imbalance of power between an aggressor and a victim. Bullying is repeated and deliberate physical harm (torture, humiliation) focused on an individual or a group of pupils who cannot or are not able to defend themselves effectively. Bullying can have multiple forms, such as teasing, humiliation, isolation, threatening, stealing money or food, physical attacks, sexual abuse or harassment. A specific form of bullying behaviour is cyberbullying. It is dangerous mainly because of the speed of informing others, timelessness and a number of the participants ([11], [12]).

\section{METHODOLOGY}

The study objective was to find out the social interactions among primary school pupils in Slovakia focused on manifestations of bullying behaviour. In the study, we were interested in the issue of perceiving bullying. We asked ourselves the questions: How do children perceive bullying if they are aggressors? How do they perceive bullying if they are victims? What are the teachers' and classmates' reactions to bullying?

Our study was conducted in the sample of 289 respondents $(n=289)$. There were $144(49.80 \%)$ boys and $145(50.20 \%)$ girls. The respondents' average age was 10.6 years $(\mathrm{SD}=0.93$; $\mathrm{Min}=7$, Max $=$ 12). The study was conducted in May 2018 in eight primary schools in various parts of Slovakia with a higher (more than $20 \%$ ) representation of Roma pupils.

As the basic method of data collection, we used questionnaire. The items stated in this paper were developed on the basis of the previous studies. For example, Participant roles questionnaire as reported in [13] or some questions were based on the example of the questionnaire by Hunter and colleagues in the attachment (see [14]). Some items were inspired by a scale in [15], but we cannot really say we adapted it.

\section{RESULTS}

In our study, we were interested in the issue of perceiving bullying. How do children perceive bullying if they are aggressors? How do they perceive bullying if they are victims? What are the teachers' and classmates' reactions to bullying?

In accordance with our findings, about $60 \%$ of our respondents did not perceive their behaviour as the one that might be labelled as bullying, or behaviour that would harm other children. 
Table 1. How often during the last school year the respondents did these things.

\begin{tabular}{|c|c|c|c|c|c|c|c|}
\hline & & Never & Rarely & $\begin{array}{l}\text { Some- } \\
\text { times }\end{array}$ & Often & $\begin{array}{l}\text { Almost } \\
\text { always }\end{array}$ & Total \\
\hline \multirow{2}{*}{$\begin{array}{l}\text { I hit or push some of my } \\
\text { classmates }\end{array}$} & $\mathrm{n}$ & 162 & 89 & 32 & 5 & 1 & 289 \\
\hline & $\%$ & 56.10 & 30.80 & 11.10 & 1.70 & 0.30 & 100.0 \\
\hline \multirow{2}{*}{$\begin{array}{l}\text { I offend or tease some of } \\
\text { my classmates by calling } \\
\text { them nasty nicknames }\end{array}$} & $\mathrm{n}$ & 173 & 70 & 37 & 5 & 3 & 288 \\
\hline & $\%$ & 60.10 & 24.30 & 12.80 & 1.70 & 1.00 & 100.0 \\
\hline \multirow{2}{*}{$\begin{array}{l}\text { I exclude or isolate some } \\
\text { classmates from the group }\end{array}$} & $\mathrm{n}$ & 196 & 49 & 27 & 11 & 2 & 285 \\
\hline & $\%$ & 68.80 & 17.20 & 9.50 & 3.90 & 0.70 & 100.0 \\
\hline \multirow{2}{*}{$\begin{array}{l}\text { I spread rumours about } \\
\text { some classmates behind } \\
\text { their backs }\end{array}$} & $\mathrm{n}$ & 172 & 71 & 35 & 6 & 2 & 286 \\
\hline & $\%$ & 60.10 & 24.80 & 12.20 & 2.10 & 0.70 & 100.0 \\
\hline
\end{tabular}

From the offered options, the pupils exclude someone from the group $(68.8 \%)$ the least. Spreading rumours and teasing the classmates, or calling them nasty nicknames are not present in $60.10 \%$ of the pupils. Hitting and pushing the classmates are present in $43.9 \%$ of the pupils.

In the study, we also wanted to know which of the stated forms and manifestations of behaviour were done to our respondents. Will the results be the same?

Table 2. How often during the last school year these things were done to the respondents.

\begin{tabular}{l|c|c|c|c|c|c|c}
\hline \hline & & Never & Rarely & $\begin{array}{c}\text { Some- } \\
\text { times }\end{array}$ & Often & $\begin{array}{c}\text { Almost } \\
\text { always }\end{array}$ & Total \\
\hline I am hit or pushed by some & $\mathrm{n}$ & 146 & 65 & 55 & 14 & 7 & 287 \\
\cline { 2 - 8 } & $\%$ & 50.90 & 22.60 & 19.20 & 4.90 & 2.40 & 100.00 \\
\hline $\begin{array}{l}\text { Slassmates } \\
\text { nasty nicknames or offend } \\
\text { me }\end{array}$ & $\mathrm{n}$ & 129 & 69 & 66 & 18 & 6 & 288 \\
\cline { 2 - 8 } & $\%$ & 44.80 & 24.00 & 22.90 & 6.30 & 2.10 & 100.00 \\
\hline $\begin{array}{l}\text { I know that someone } \\
\text { spreads nasty rumours } \\
\text { about me when I can't hear }\end{array}$ & $\mathrm{n}$ & 127 & 69 & 54 & 30 & 6 & 286 \\
\cline { 2 - 9 } & $\%$ & 68.80 & 24.10 & 18.90 & 10.50 & 2.10 & 100.00 \\
\hline $\begin{array}{l}\text { I am excluded or isolated } \\
\text { from the group }\end{array}$ & $\mathrm{n}$ & 196 & 40 & 32 & 9 & 4 & 281 \\
\cline { 2 - 9 } & $\%$ & 69.80 & 14.20 & 11.40 & 3.20 & 1.40 & 100.00 \\
\hline \hline
\end{tabular}

Based on the findings, almost half of the respondents $(49.10 \%)$ were affected by hitting or pushing by some classmates in some extent. Even a higher frequency of occurrence was found in perceptions of calling them nasty nicknames. Only $44.80 \%$ of the respondents stated that during the last year they were never called nicknames they perceived negatively. The information that someone spreads rumours about the respondents was not noticed by $68.80 \%$ of the respondents. Also, almost the same percentage of answers was obtained in perceptions of being excluded from the group. On the other hand, more than $30 \%$ of the pupils faced isolation from the group. 
Table 3. Causes of nasty behaviour against the respondents

\begin{tabular}{l|c|c|c|c|c|c|c}
\hline \hline $\begin{array}{l}\text { When one or more } \\
\text { classmates do bad things } \\
\text { to me, it is because... }\end{array}$ & & Never & Rarely & $\begin{array}{c}\text { Some- } \\
\text { times }\end{array}$ & Often & $\begin{array}{c}\text { Almost } \\
\text { always }\end{array}$ & Total \\
\hline \multirow{2}{*}{ of my weight } & $\mathrm{n}$ & 237 & 21 & 18 & 6 & 6 & 288 \\
\cline { 2 - 8 } & $\%$ & 82.30 & 7.30 & 6.30 & 2.10 & 2.10 & 100.00 \\
\hline \multirow{2}{*}{ of my additional needs } & $\mathrm{n}$ & 254 & 17 & 11 & 4 & 0 & 286 \\
\cline { 2 - 9 } & $\%$ & 88.80 & 5.90 & 3.80 & 1.40 & 0.00 & 100.00 \\
\hline \multirow{2}{*}{ of my home country } & $\mathrm{n}$ & 266 & 12 & 9 & 0 & 2 & 289 \\
\cline { 2 - 9 } of my religion & $\%$ & 92.00 & 4.20 & 3.10 & 0.00 & 0.70 & 100.00 \\
\hline \multirow{2}{*}{ of my skin colour } & $\mathrm{n}$ & 268 & 12 & 5 & 3 & 1 & 289 \\
\cline { 2 - 8 } & $\%$ & 92.70 & 4.20 & 1.70 & 1.00 & 0.30 & 100.00 \\
\hline \multirow{2}{*}{ of other reason } & $\mathrm{n}$ & 251 & 11 & 15 & 8 & 2 & 287 \\
\cline { 2 - 8 } & $\%$ & 87.50 & 3.80 & 5.20 & 2.80 & 0.70 & 100.00 \\
\hline \hline
\end{tabular}

The reasons of negative behaviour against classmates are perceived in various ways. In our study, we primarily focused on prejudice-based bullying. We found out that approximately $10 \%$ of the respondents perceives that different skin colour, religion, home country, etc. are the reasons of negative behaviour against them. Among our respondents, however, the ways of behaviour that did not relate to prejudice but to weight, glasses, clothes, good grades, talent, etc. were more frequent. These other reasons were more dominant than prejudice-based bullying.

Of course, we were curious about perceptions of who should stop these negative manifestations of behaviour. How do the respondents perceive reactions by their teachers in such unpleasant situations?

Table 4. Teachers' reactions to bullying as perceived by pupils.

\begin{tabular}{l|c|c|c|c|c|c|c}
\hline & & $\begin{array}{c}\text { Very } \\
\text { untrue }\end{array}$ & $\begin{array}{c}\text { A little } \\
\text { untrue }\end{array}$ & $\begin{array}{c}\text { Neither } \\
\text { untrue } \\
\text { nor true }\end{array}$ & True & Very true & Total \\
\hline \multirow{2}{*}{$\begin{array}{l}\text { My teachers have stopped } \\
\text { the bullying }\end{array}$} & $\mathrm{n}$ & 57 & 37 & 54 & 97 & 36 & 281 \\
\cline { 2 - 8 } & $\%$ & 20.30 & 13.20 & 19.20 & 34.50 & 12.80 & 100.00 \\
\hline $\begin{array}{l}\text { My teachers thought that I } \\
\text { should stop the bullying, if } \\
\text { they were not present }\end{array}$ & $\mathrm{n}$ & 139 & 48 & 53 & 21 & 16 & 277 \\
\cline { 2 - 9 } $\begin{array}{l}\text { My teachers thought that I } \\
\text { should inform an adult, if } \\
\text { they were not present }\end{array}$ & $\mathrm{n}$ & 103 & 38 & 32 & 65 & 38 & 276 \\
\cline { 2 - 9 } $\begin{array}{l}\text { My teachers believed that I } \\
\text { should do nothing, because }\end{array}$ & $\mathrm{n}$ & 137.30 & 13.80 & 11.60 & 23.60 & 13.80 & 100.00 \\
\cline { 2 - 9 } $\begin{array}{l}\text { it is not my business, if they } \\
\text { were not present }\end{array}$ & $\%$ & 47.30 & 18.40 & 15.50 & 12.30 & 6.50 & 100.00 \\
\hline $\begin{array}{l}\text { My teachers preferred me to } \\
\text { not do anything, because I } \\
\text { could get in trouble, if they } \\
\text { were not present }\end{array}$ & $\mathrm{n}$ & 132 & 53 & 52 & 23 & 19 & 279 \\
\hline \hline
\end{tabular}

According to the respondents, almost half of the respondents agree that bullying must be stopped by teachers. They do not agree with the statement that the teacher would think pupils should resolve the situation $(50.20 \%)$. Similarly, half of the pupils think that pupils should inform an adult if they were not 
present $(51.10 \%)$, or believe they should do nothing, because it is not their business, if they were not present $(65.7 \%)$. Two thirds of the respondents $(66.30 \%)$ do not agree with the statement that their teachers preferred pupils to not do anything, because they could get in trouble, if they were not present.

The same items were used related to the reactions to bullying by respondents' best friends.

Table 5. How did best friends react to bullying?

\begin{tabular}{l|c|c|c|c|c|c|c}
\hline \hline & & $\begin{array}{c}\text { Very } \\
\text { untrue }\end{array}$ & $\begin{array}{c}\text { A little } \\
\text { untrue }\end{array}$ & $\begin{array}{c}\text { Neither } \\
\text { untrue } \\
\text { nor true }\end{array}$ & True & $\begin{array}{c}\text { Very } \\
\text { true }\end{array}$ & Total \\
\hline \multirow{2}{*}{$\begin{array}{l}\text { My best friends in the class } \\
\text { have stopped the bullying }\end{array}$} & $\mathrm{n}$ & 79 & 48 & 82 & 55 & 19 & 284 \\
\cline { 2 - 8 } & $\%$ & 27.80 & 16.90 & 28.90 & 19.40 & 6.70 & 100.00 \\
\hline $\begin{array}{l}\text { My best friends in the class } \\
\text { thought that I should stop } \\
\text { the bullying }\end{array}$ & $\mathrm{n}$ & 128 & 51 & 64 & 33 & 5 & 281 \\
\cline { 2 - 8 } & $\%$ & 45.60 & 18.10 & 22.80 & 11.70 & 1.80 & 100.00 \\
\hline $\begin{array}{l}\text { My best friends in the class } \\
\text { thought that I should inform } \\
\text { an adult }\end{array}$ & $\mathrm{n}$ & 95 & 36 & 43 & 81 & 30 & 285 \\
\hline & $\%$ & 33.30 & 12.60 & 15.10 & 28.40 & 10.50 & 100.00 \\
\hline $\begin{array}{l}\text { My best friends in the class } \\
\text { believed that I should do } \\
\text { nothing, because it is not } \\
\text { my business }\end{array}$ & $\mathrm{n}$ & 105 & 54 & 70 & 39 & 15 & 283 \\
\cline { 2 - 8 } & $\%$ & 37.10 & 19.10 & 24.70 & 13.80 & 5.30 & 100.00 \\
\hline $\begin{array}{l}\text { My best friends in the class } \\
\text { preferred me to not do } \\
\text { anything, because I could } \\
\text { get in trouble }\end{array}$ & $\mathrm{n}$ & 98 & 48 & 54 & 59 & 21 & 280 \\
\cline { 2 - 9 } & & 35.00 & 17.10 & 19.30 & 21.10 & 7.50 & 100.00 \\
\hline \hline
\end{tabular}

From the responses, we did not get unambiguous results as it was in the items related to teachers. Almost half of best friends (44.7\%) did not stop bullying if it occurred. According to the respondents, their best friends did not even think that bullying should be stopped by the respondents themselves $(13.50 \%)$. According to $38.90 \%$ of them, they thought that the respondent should inform an adult to resolve bullying. Only $19.10 \%$ of the respondents think that their best friends in the class believed that respondents should do nothing, because it is not their business. More than half of the respondents $(52.10 \%)$ stated that they did not agree with the statement that their best friends in the class preferred respondents to not do anything, because they could get in trouble.

\section{CONCLUSIONS}

The results suggest that there is a difference in perceiving bullying in peer interactions. In the studied sample, the children assessed their behaviour in the intentions of partial forms of bullying related to their own behaviour towards their classmates and related to experienced behaviour of their classmates towards them. The results show that in case of pushing, calling them nasty nicknames and spreading rumours, there is a difference in perceptions of bullying behaviour. We identified $13.1 \%$ of the pupils who stated that during the last year they pushed or hit their classmates (we analysed the frequency: rarely, often, always); there were $26.5 \%$ of the pupils who were pushed or hit by their classmates rarely, often and always during the year. Similar differences were found in cases of nasty nicknames (I offend my classmates $15.50 \%$ vs. My classmates give me nasty nicknames $31.30 \%$ ) and spreading rumours (I spread rumours $15.00 \%$ vs. They spread rumours about me behind my back $31.50 \%$ ). An interesting finding is that perceived exclusion from the group of classmates and also behaviour which excludes others from the group have the same percentages. The area of isolation, the situation when I do not have a status in the group (or I do not have a right to have one) is exactly the same in the subjective description on one's behaviour and experiencing (I exclude others from the group $14.10 \%$ vs. I feel excluded $16.00 \%$ ). The reasons for excluding someone from the group may be the characteristics related to pupils' appearance, ethnicity, or socioeconomic status. In our sample, the respondents perceived as rare, frequent or permanent reasons for bullying/bad behaviour in their classmate/classmates towards them in $19.70 \%$ differences in appearance (glasses, clothes, good grades, etc.), $10.50 \%$ being overweight, and $8.70 \%$ skin colour (NB: In Slovakia, most 
often pupils who differ in skin colour, or ethnicity in the classes are Roma pupils). In the interviews, the pupils in our sample stated:

"We had a classmate who had to leave for another school because he was harmed by another boy. He did bad things to him, teased him, hid his things, and so on. He was a clever pupil. He could not prevent it. But that boy does bad things to everyone. But only seldom. He harmed him often."

"There are situations in which pupils from other classes shout at me that I am fat."

"The girls told me not to touch their desk because I am a Gypsy. Children did not want to hold my hand."

Social groups have their dynamics and regulations. In the school environment, however, the external regulators are pedagogues and school with the rules and culture. The study respondents consider teachers to be an authority who is responsible for stopping bullying $(66.50 \%)$. Also, in the interviews they stated that they report the manifestations of bullying behaviour to the teacher or headmaster. An average age of the pupils participating in our study was 10.6 years, and also related to their age, we state that the respondents do not feel competent yet to stop the aggressors or do something for the victims. It turns out that in work with school-aged pupils it is necessary to focus attention on strengthening the self-worth in peer interactions and the skill of self-defence in communication. Furthermore, it is important to work on the formation of the class group and focus on sensitivity to differences between pupils.

\section{ACKNOWLEDGEMENTS}

This research was supported by Erasmus+ project 2017-1-UK01-KA201-036611 Using a GAmes approach to TEach children about discriminatory BULLying (GATE-BULL)

\section{REFERENCES}

[1] P. Macek, Adolescence. Praha: Portál, 2003.

[2] J. Santrock, Adolescence. New York: McGraw Hill, 2013.

[3] R. Braun, D. Marková, J. Nováčková, Praktikum školní psychologie. Praha:Portál, 2014.

[4] M. Kolář, Nová cesta k léčbě šikany. Praha: Portál, 2011.

[5] P. Řičan, P. Janošová, Jak na šikanu. Praha: Grada, 2010.

[6] M. Čerešník, Hraničná zóna. Nitra: UKF, 2016.

[7] D. A. Olweus, "Sweden" in The nature of school bullying: A cross-national perspective (P.K. Smith, Y. Morita, J. Junger-Tas, D. Olweus, R. Catalano, P. Slee, eds.), pp 7-27, London: Routledge, 1999.

[8] A. G. Carney \& K. W. Merrell," Bullying in Schools: Perspectives on Understanding and Preventing an International Problem," School Psychology International, vol. 22, No. 3, pp. 364382, 2001.

[9] G.M. Glew, M. Z. Fan, W. Katon, F.P. Rivara, \& M.A. Kernic, "Bullying, psychosocial adjustment, and academic performance in elementary school," Archives of Paediatrics and Adolescent Medicine, vol. 159, no. 11, pp. 1026-103, 2005.

[10] M. Širůčková, "Rizikové chování a jeho psychosociální souvislosti" in: Primární prevence rizikového chování (M.Miovský, J. Zapletalová, P. Novák eds.), s.. 30-39, Tišnov, Praha: Sdružení SCAN, Centrum adiktologie, Psychiatrická klinika, 1. LF UK v Praze a VFN v Praze; Togga, 2010.

[11] J.M. Price \& J. Dalgleish, "Cyberbullying: Experiences, impacts and coping strategies as described by Australian young people," Youth Studies Australia, vol. 29, no. 2, pp. 51-59, 2010.

[12] A. Černá a kol., Kyberšikana. Průvodce novým fenoménem. Praha: Grada, 2013.

[13] T. Pozzoli \& G. Gini, "Active defending and passive bystanding behavior in bullying: The role of personal characteristics and perceived peer pressure," Journal of Abnormal Child Psychology, vol. 38, pp.815-827, 2010. 
[14] K. Durkin, S. Hunter, K.A. Levin, D. Bergin, D.Heim \& C. Howe, "Discriminatory peer aggression among children as a function of minority status and group proportion in school context,"

European Journal of Social Psychology, vol 42, no.2, pp. 243-251, 2012.

[15] M.E. Boyes, S.J. Mason, \& L.D. Cluver, "Validation of a brief stigma-by-association scale for use with HIVIAIDS-affected youth in South Africa," AIDS Care, vol.25, no. 2, pp. 215-222, 2013. 